\title{
TRANSFORMATION OF COMMUNICATIVE AND EMOTIONAL VALUES IN RUSSIAN LINGUOCULTURE
}

\author{
Yana A. Volkova \\ Peoples’ Friendship University of Russia, Moscow, Russia \\ Nadezhda N. Panchenko \\ Volgograd State Social-Pedagogical University, Volgograd, Russia
}

\begin{abstract}
Values are generally accepted guidelines that are important for the formation, development and existence of both the individual and society. In his communicative practice, a person relies on universal and culturally-based values, which, in turn, are subject to evolution or degradation at various stages of social development. The authors of the article, guided by the idea of the flexibility and variability of values in certain historical epochs, attempt to demonstrate that at present, due to social and cultural processes, communicative and emotional values in Russian linguistic culture undergo certain change, which transforms the existing system of values. The researchers' attention is focused on such communicative values as truth and modesty, which seem to be unconditional and absolute moral and ethical guidelines for representatives of Russian linguistic culture. The analyzed material from the National Corpus of the Russian language, Internet forums and examples from live conversation show that in the modern Russian-speaking consciousness, truthful and modest communicative behavior is interpreted and evaluated a little differently than before. Similar to communicative values, the value of emotions is also subject to transformation. As an example of the inversion of the linguocultural value of emotions, we consider the emotion of anger, which is among the universal human emotions. The analysis of modern feature films allows us to conclude that anger and other destructive emotions of the protagonist can be recognized as a constructive force that changes the world for the better, and its positive assessment leads to such behavior being socially approved in real life.
\end{abstract}

Key words: communication, communicative behavior, linguoculture, value, emotion, inversion.

Citation. Volkova Ya.A., Panchenko N.N. Transformation of Communicative and Emotional Values in Russian Linguoculture. Vestnik Volgogradskogo gosudarstvennogo universiteta. Seriya 2. Yazykoznanie [Science Journal of Volgograd State University. Linguistics], 2020, vol. 19, no. 2, pp. 54-65. DOI: https://doi.org/10.15688/jvolsu2.2020.2.5

\section{ТРАНСФОРМАЦИЯ}

\section{КОММУНИКАТИВНЫХ И ЭМОЦИОНАЛЬНЫХ ЦЕННОСТЕЙ В РУССКОЙ ЛИНГВОКУЛЬТУРЕ}

\author{
Яна Александровна Волкова \\ Российский университет дружбы народов, г. Москва, Россия;
}

\section{Надежда Николаевна Панченко}

Волгоградский государственный социально-педагогический университет, г. Волгоград, Россия

Аннотация. В статье с опорой на положение о вариативности ценностей в определенные исторические эпохи установлено, что коммуникативные и эмоциональные ценности в русской лингвокультуре на современном этапе претерпевают изменения, которые обусловливаются социальными и культурными процесса- 
ми и трансформируют существующую систему ценностей. Внимание авторов сосредоточено на таких коммуникативных ценностях, как правда и скромность. На материале Национального корпуса русского языка, интернет-форумов и примеров наблюдений за живым разговорным общением показано, что в современном русскоязычном сознании правдивое и скромное коммуникативное поведение осмысливается и оценивается несколько иначе, чем раньше: оно перестает быть безусловным и абсолютным морально-нравственным ориентиром. Выявлено, что трансформации подвержена ценность эмоций. В качестве примера таких изменений рассмотрена инверсия лингвокультурной ценности гнева, являющегося одной из универсальных человеческих эмоций. На материале современных художественных фильмов сделан вывод о том, что гнев и другие деструктивные эмоции главного героя осознаются как конструктивная сила, изменяющая мир к лучшему, а их положительная оценка обусловливает подобное поведение в реальной жизни как социально одобряемое.

Ключевые слова: коммуникация, коммуникативное поведение, лингвокультура, ценность, эмоция, инверсия.

Цитирование. Волкова Я. А., Панченко Н. Н. Трансформация коммуникативных и эмоциональных ценностей в русской лингвокультуре // Вестник Волгоградского государственного университета. Серия 2 , Языкознание. - 2020. - Т. 19, № 2. - С. 54-65. - (На англ. яз.). - DOI: https://doi.org/10.15688/jvolsu2.2020.2.5

\section{Introduction}

Any society possesses a number of moral standards that people are guided by in the process of their formation and socialization. Such moral universally recognized standards and norms are called universal or (in the terminology of S.A. Bibi and T.P. Motet) transcultural human values that create the moral "portrait" of a person [Bibi, Motet, 2007]. Such values account for the sociopsychological factor of human existence and provide for our emotional needs.

When choosing a type of communicative behavior, an individual is guided not only by universal human values, formed in the process of biological and social development of human civilization, but also by culturally-based values, as well as individual needs, motives and goals.

There is an opinion that national values, if they do exist (italics added), cannot be opposed to universal values [Komarov, 2013, p. 24]. It seems that values after in various spheres of public life, in different national or/and cultural groups in certain historical periods. It is quite natural to talk about the linguocultural specificity of the basic universal values, revealed in crosscultural communication. In addition, human values inevitably evolve along with humanity, social progress and cultural change. They can also degrade or devolve, get stereotyped, gradually turning into "frozen", strictly formal means of assessing the situation [Tsennosti $i$ kommunikatsiya..., 2012, p. 7-8]. In particular, V.V. Dement'ev states that such concepts as sincerity, openness, directness, sociability, emotionality, restraint, reticence, obedience are no longer absolute values. These and many other concepts are always evaluative, but contain (at least in Russian culture) a fundamentally ambivalent value [Dementyev, 2010, p. 259]. In this regard, the study of the value dynamics allows us to describe the society's cultural dominants recorded in the language.

The purpose of this article is to analyze the shifts in communicative and emotional values that have taken place in Russian linguistic culture, on the example of the communicative concepts 'правда' ('truth') and 'скромность' ('modesty') and the emotional concept 'гнев' ('anger'). Explanatory dictionaries, examples from the Russian National Corpus, online forums and excerpts from live conversations are used as empirical material for the research.

The theoretical and methodological framework for the present study includes the works of foreign and domestic linguists in the fields of communication theory, emotive linguistics and linguocultural studies (A. Wierzbicka, V.V. Dement'ev, G. Leech, P. Ekman, C. Izard, Z. Kövecses and others).

\section{Results and discussion}

\section{Shifting communicative values}

'Правда' ('truth') and truthful behavior. Truth, along with respect for the dignity of another person and non-harming the innocent, is included in the prototypical norms that correlate with universal pan-cultural values [Bibi, Motet, 2007]. Undoubtedly, truth is one of the fundamental, universal values; it is recognized as a moral behavioural norm, positively perceived and shared 
by most people regardless of national and cultural identity. Being included in the axiological space of communication, truth is one of the regulators of human communicative behaviour that affects the addressee's choice of language tools, as well as communicative strategies and tactics.

In discourse, values can be expressed by maxims of moral, religious nature. The communicative value of truthful behaviour is traditionally stated as the norm and principle of behaviour: "One should be honest"; the preference for any truth, even harmful and causing emotional discomfort "Bad truth is better than good lies", is recorded in the opposition model "truth / value - lie / anti-value".

According to A. Wierzbicka, in Russian culture, 'truth' (or 'правда') is closely related to telling other people what one thinks: "The notion of dialogue does not imply 'opening oneself' for another person, let alone 'opening another person', and even the idea of 'making another person open him- or herself' goes far beyond the meaning of the English word dialogue (and beyond the prevailing Anglo expectations and norms)" [Wierzbicka, 2002, p. 425].

However, one cannot fail to notice that in the Russian language consciousness, truth is associated with the concept of 'struggle'. It is believed that truth has always been the goal of a righteous life for a Russian person, so people fought for it and died, sacrificed themselves for the sake of truth, were sent away to do hard labour [Yakovleva, 1998, p. 134]. It is no coincidence that in the Russian language, we can come across such nominations as правдоруб (truthteller), правдоискатель (truth seeker), правдобореи, бореи за правду (truth fighter), as well as peзать / рубить правду-матку, лепить правду, выбрить всю правду в глаза (to be brutally honest, to tell the truth flat out), Хлеб-соль ешь, а правду (матку) режь (tell the truth under any circumstances), etc. Therefore, it is obvious that the value component of the communicative type 'правдолюб' ('truth lover')in Russian linguistic culture is represented by ambivalent characteristics.

According to the conducted survey (130 respondents aged from 18 to 74 ), on the one hand, truth lovers are sincere, honest people, who feel abhorrence of hypocrisy; mind, honour and conscience; people who want to make life better
(57\% of informants). On the other hand, they are people who do not like someone else's truth / have their own understanding of truth (seeking the truth, which is often true only for them); love what they believe to be true; not always sincere and honest, but require this from others; troublemakers and squabblers (40\%). The latter allows us to attribute truth lovers to a conflict-aggressive type of linguistic personality.

Only 3\% of respondents revealed a neutral attitude towards the truth lover and his communicative behavior.

The prevailing number of respondents who positively evaluate the social significance of truthlovers' communicative behavior could be explained by the socially approved proactive attitude and initiative of a citizen who unveils real or alleged facts of lawbreaking.

As A. Wierzbicka rightly observes, such phrases as "rezat' pravdu v glaza (to cut the truth into somebody's eyes) show that russians are well aware of the painful effect that truth-telling may have on the listener. Yet the same expressions and sayings also suggest that telling the truth may stand higher in the hierarchy of values than any consideration for the interlocutor's feelings" [Wierzbicka, 2002, p. 421].

The communicative behavior of a truth lover is partially similar to the communicative behavior of a critic who accuses others of unseemly acts. In most cases, a truth lover, who acts as a castigator of vices, demonstrates a strong attitude against a communicative partner, which is expressed through a certain amount of hostility, aggressiveness, and negatively charged emotional behavior. Here are a few quotes from the survey to illustrate this statement: unpredictable; intolerant; tactless; difficult to communicate; conflicting; critical; speaks harshly; harms others; does not know how to develop relationship with other people; it is difficult to find a common language with such a person; unable to control his / her temper, or step back; believes that he is always right; inadequately evaluates the situation; often pursues selfish goals, while protecting the truth, he lies.

Psychologists confirm that uncompromising behavior, impeccable honesty and the pursuit of truth at any cost may, in some cases, indicate a peculiar way of "settling one's scores", motivated by resentment, envy or aggression. In other 
situations, it might indicate confidence in one's own superiority and perfection, which allows pointing to others' shortcomings.

Such truthful behavior, characterized by an open demonstration of one's position, is accompanied by a sharp, emotionally unrestrained tonality, black-and-white assessments, and low colloquial or obscene vocabulary. As a result, truthfulness being a conscious adherence to the truth and a feature of a social subject determining the presumption of communication does not always work as an unconditional communicative value in Russian linguistic culture. The respondents suggest using a measured amount of truth that is harmful to interpersonal relationships: "sometimes it is better to keep your opinion to yourself", "the ability to remain silent, keep your opinion to yourself and be flexible is somewhat more important than the search for the truth", "it does not always help in life", "the truth can kill", "pravda-matka can hurt".

The duality of the perception of the communicative value / anti-value of truth in modern Russian linguistic culture can be explained by the ongoing social transformations, globalization processes and cultural changes observed in our society, a tendency to displace old values and replace them with new Western ones (remember a billboard slogan: Забей на всё, садись за руль! (Kick back, get behind the wheel!). In our opinion, it is not unexpected that in the survey, those respondents who recognized the truth lover as the bearer of virtue and the embodiment of morality, and who advocated unconditional truthfulness in everything, were older people (mostly aged between 61 and 74), while the younger respondents (mainly between 18 and 55) view the truth lover as a conflicting, destructive personality type that does not take into account the addressee's reaction.

Thus, we are not talking about two opposed systems of communicative values within the framework of the same linguistic culture, but about their gradual inversion: adherence to truth as a communicative ideal is no longer always correlated with linguistic and cultural values, but is turning into a variant of conflicting behavior, while a lie, inherent to any human behavior, regardless of culture and specific language, noncompliant with the fundamental norms of behavior, is becoming more preferable when it neutralizes direct emotional harm to the communicative partner and/or prevents noncooperative behavior.

'Скромность' ('modesty') as a behavioural concept. In terms of thematic relevance, the concept of modesty is a kind of behavioral concept. In this regard, it is appropriate to recall the term "emotional behavioral concept", as it was introduced in the doctoral dissertation by I.I. Chesnokov [Chesnokov, 2009]. In his work, the scientist defines the emotional behavioral concept as a unit of the mental level of knowledge organization, biologically determined, socially processed, and possessing a symbolic, including linguistic, form; at the same time, linguistic semantics is considered as an arena of dialectical interaction of the unconscious and value-normative culture settings [Chesnokov, 2009, p. 6]. Using a Russian concept 'месть' ('revenge') as an example, the author considers the emotional behavioral concept as a model of behavior (activity), reflected in the individual's consciousness. It is described in terms of social interaction - to a motive, goal, as well as strategies and tactics for achieving it. Following the logic of the author and taking into account the specifics of the phenomenon understudy, we admit the possibility of considering the concept 'скромность' ('modesty') as a behavioral communicative concept objectified in a sign (language) form, since the human mind has a certain behavior model that can be described, on the one hand, in terms of the psychological genesis of modesty, and, on the other, in terms of social interaction between people, from the perspective of the speaker who is using certain maxims in communication to reach his communicative goal. According to G. Leech, the maxim of modesty as one of the conditions for the success of communicative interaction implies minimizing the expression of praise of the self [Leech, 1983]. The example below supports this judgment:

(1) Казалось, что он всегда равнодушен к похвалам, потому что какая-то врожденная интеллигентская скромность никогда не позволяла ему нести, что называется, «бремя славы» с гордо поднятой головой (Висков А. Наследник апостола Иоанна // Наш современник. 2004. 15 июня. Национальный корпус русского языка (НКРЯ). He seemed to have always been indifferent to praise, because some kind of innate "intelligentskaja" modesty 
never allowed him to bear what is called the "burden of glory" with his head held high (Viskov A. Naslednik apostola Ioanna // Nahs sovremennik. 2004. 15 June. Russian National Corpus (RNC) (hereinafter translated by Ya. Volkova and N. Panchenko).

In terms of the evaluative component of the concept and its correlation with certain values of linguistic culture, modesty is expediently attributed to regulatory mental formations in which the value component is represented quite significantly. The latter accounts for the relevance of our addressing this communicative phenomenon, and allows us to characterize it as a concept that defines the norms of communicative behavior.

We would like to emphasize that we do not claim it to be a complete description of this concept. In this paper, we attempt to show that modesty is interpreted and experienced in the modern Russian-speaking consciousness a little differently than before. A new perception of this concept transforms the existing system of values, redefining the guidelines for the behavior of representatives of Russian linguistic culture.

In Russian, скромныц̆ (modest) etymologically goes back to Polish *krom "granitsa" ("border"): derived from *krom-; cf. кро́мы pl. "weaver's loom”, which is related to OHG (h)rama "frame", originally "one who keeps within the limits / frame, reserved (Fasmer, p. 658-659); one who keeps within the limits / frame, restrained (Shanskiy, Bobrova).

In Russian, the word скромность (modesty) is used both to characterize personal qualities and human behavior, and to describe the properties of objects. For instance, Dictionary of the Modern Russian Literary Language offers the following interpretation of the word скромныли:

Скромный, -аја, -ое; -men, -тnа, -о. 1. Not in the habit of emphasizing their merits, boasting about their merits; devoid of vanity, arrogance. 2. Restrained, moderate in behavior, manners, words. 3. Indicative of good manners, restraint, moderation in behavior, conversation; expressing such restraint, moderation. 4. Nothing outstanding, simple, unpretentious; ordinary; no claim to luxury, wealth. 5. Small, insignificant (Slovar sovremennogo russkogo literaturnogo yazyka, vol. 13, col. 1068) (hereinafter translated by Ya. Volkova and N. Panchenko).
A similar interpretation can be found in other explanatory dictionaries:

1. Discreet in revealing their merits; merits, not boastful. 2. Restrained, moderate, simple and decent. 3. Fig. Small, limited, barely sufficient (Ozhegov); 1. One that does not seek to show his / her qualities, dignity, merit, devoid of haughtiness and arrogance. 2. Possessing moderation in everything, sufficient shyness, not too cheeky, quite decent, proper. 3. Simple, without claims to luxury, wealth or special elegance (Ushakov).

Thus, the core component of the concept in terms of describing modesty as a personality trait can be represented through a series of negative definitions: not boastful, not arrogant, not showing off their accomplishments and merits. A modest person is characterized by moderation, simplicity, restraint. Items possessing this property are characterized by the presence of some quality to a small extent (small size, wealth, etc.), are not known for beauty, complexity, grace.

It seems interesting to point out that the illustrative material presented in the explanatory dictionaries reflects a positive social evaluation of modesty as a personality trait:

(2) Помните, что цельная натура, настоящий человек, как правило, - скромный и даже робкий (Матвеев, Семнадцатилетние. Словарь русского литературного языка, т. 13, стб. 1068). - Remember that a man of integrity, a real person, as a rule, is modest and even timid (Matveev, The Seventeen-Year-Olds. Slovar sovremennogo russkogo literaturnogo yazyka, vol. 13, col. 1068).

So, the core of this concept is a kind of positive personality trait, consisting in the absence of such negative qualities as boasting, vanity, arrogance, haughtiness. Like other concepts related to the representation of the human inner world, 'скромность' is characterized by the presence of an evaluative component in the structure of its definition simultaneously with the fuzziness of the core conceptual component. It seems to us that the content of the concept 'скромность' is much broader than its core component described above and can be revealed through identifying a system of oppositional concepts. These concepts can be revealed by means of the analysis of compatibility and reflection contexts; they focus attention on various 
aspects of the concept under study. First of all, let us point out that all the identified oppositional models can be divided into two groups: a) correlated with the "domestic" domain and b) characterizing the communicative behaviour of a person. As applied to the real world, to the way of dressing, in particular, скромность implies the absence of luxury and pretentiousness, is opposed to luxury (modesty (simplicity, unpretentiousness) $\leftrightarrow$ luxury, brightness, attractiveness, pretentiousness):

(3) Сибуй - это простота и скромность. Роскошь и чрезмерность - первый признак пошлости (Соколов-Митрич Д. Идеальные православные // Русский репортер. 2012. НКРЯ). - Shibui is simplicity and modesty. Luxury and excessiveness are the first sign of vulgarity (Sokolov-Mitrich D. The Perfect Orthodox Christians // Russkiy reporter. 2012. RNC).

As a feature of communicative behavior, modesty in a naive Russian-speaking consciousness is primarily associated, and often synonymous, with shyness and humbleness (modesty (shyness, humbleness, timidity) $\leftrightarrow$ arrogance, selfconfidence):

(4) Вы меня пропесочили за скромность. Женщины любят тех, кто понахальней (Гранин Д. Нина // Дружба народов. 1999. 15 мая. НКРЯ). - You criticized me severely for modesty. Women love those who are more impudent (Granin D. Nina // Druzhba narodov. 1999. 15 May. RNC).

The basis for such behavior is self-doubt and low self-esteem, which can develop into an inferiority complex (modesty (as low selfesteem) $\leftrightarrow$ boasting / bragging):

(5) - Какая скромность! Какая неуверенность в себе! (Есин С. Имитатор. 1985. НКРЯ). - What modesty! What self-doubt! (Yesin S. The Copyist. 1985. RNC).

Focusing on the psychological sources and causes of modesty, including excessive shyness and insufficient skills, it is contrasted to verbosity (modesty (as the lack of talkativeness, restraint) $\leftrightarrow$ verbosity, eloquence):

(6) Природная скромность не мешала ему блистать красноречием и образованностью (Галяндин А. Гений мирного Рима // Знание - сила. 2006. НКРЯ). - Natural modesty did not prevent him from shining with eloquence and education (Galyandin A. The Genius of Peaceful Rome // Znanie sila. 2006. RNC);
(7) Главная их добродетель - скромность и молчание (Розанов В. Бердяев о молодом московском славянофильстве. 1916. НКРЯ). - Their main virtue is modesty and silence (Rozanov V. Berdyaev About the Young Moscow Slavophilism. 1916. RNC).

Modesty as communicative restraint and briefness can be specified in a situation requiring caution in statements, the ability to keep other people's secrets (modesty (ability to keep your mouth shut) $\leftrightarrow$ talkativeness):

(8) Хорошо! Я расскажу вам всё. Я целиком полагаюсь на вашу скромность и на скромность вашего коллеги доктора Ватсона (Масленников И., Дойль А. К. Приключения Шерлока Холмса и доктора Ватсона // Двадцатый век начинается, к/ф. НКРЯ). Well! I will tell you everything. I rely entirely on your modesty and on the modesty of your colleague Dr. Watson (Maslennikov I., Doyle A.C. The Adventures of Sherlock Holmes and Dr. Watson // The Twentieth Century Begins, motion picture. RNC);

(modesty (invisibility) $\leftrightarrow$ self-presentation):

(9) Главным в нем была скромность, невыпячивание. Когда папа садился, точнее, его сажали в какой-то президиум, - надо было искать его с биноклем, так он забивался, прятался за чьи-то спины (Волчек Г. «Верю во взаимность во всем, не только в любви» // Огонек. 2013. НКРЯ). - The main thing in him was modesty, non-showing off. When dad sat down, or rather, they put him in some kind of presidium, it was necessary to look for him with binoculars, as he would hide, hide behind someone else's back (Volchek G. "I Believe in Reciprocity in Everything, not Just in Love" // Ogonyok. 2013. RNC).

Separately, gender-marked modesty should be distinguished, which is correlated with the behavior of a girl / woman, which is synonymous with a) chastity - in (10), b) humility /humbleness - in (11) (modesty (humility, compliance, agreement) $\leftrightarrow$ objection, disagreement):

(10) Это заметно трогало Софью и тоже вызывало у нее смущение, целомудренную скромность (Горький М. Мать. 1906. НКРЯ). - This touched Sophia quite a bit and also caused her embarrassment, chaste modesty (Gorky M. Mother. 1906. RNC);

(11) Писатель полюбил Машу за скромность и покладистость (Про себя // Столица. 1997. 28 окт. НКРЯ). - The writer fell in love with Masha for modesty and compliance (About Myself // Stolitsa. 1997. 28 Oct. RNC). 
The stereotype of modesty correlates by association with the image of a Soviet person and is verbalized through a description of non-verbal components of communication - a down look, downcast eyes, which are usually indicators of embarrassment:

(12) Мы искоса на нее посматривали, а она сидела, скромно потупив глаза (Ефимов Б. Десять десятилетий. 2000. НКРЯ). - We've been glancing at her sidelong, and she sat with her eyes modestly lowered (Efimov B. Ten Decades. 2000. RNC).

For a long time, modesty was one of human virtues (cf. the motto "modesty adorns a person"), a communicative ideal and a socially approved phenomenon: it is no coincidence that it was considered a characteristic feature of a Soviet person:

(13) Тем более люди старшего поколения, воспитанные в те спорные времена, когда слова «скромность», «долг» и «обязанность» произносились без иронии (Буцик Ю. Накануне юбилея // Уральский автомобиль (Миасс). 2004. 17 янв. НКРЯ). Moreover, older people raised in those disputed times when the words "modesty", "duty" and "responsibility" were pronounced without irony (Butsik Yu. On the Eve of the Anniversary // Uralskiy avtomobil (Miass). 2004. 17 Jan. RNC).

Some researchers conclude that, when based on the paremiae analysis, the evaluative characteristics of the concept 'скромность' ('modesty') may be called ambivalent: there are both positive and negative characteristics present [Prosvirnina, Shao, 2013]. It should be emphasized that the negative characteristics are not explicitly expressed in Russian paremiae, but are introspectively deduced by the authors from the concepts opposed to modesty, such as arrogance, bashfulness, etc. Nevertheless, it should be noted that in the vast majority of Russian paremiae, modesty is undoubtedly evaluated as a positive quality (Скромность украшает человека / Modesty adorns a person; Любому молодиу скромность к лииу / Modesty suits any young man; Гордость пучит, скромность учит / Pride puffs, modesty teaches; Тому и nочет огромный, кто скромный / To that a huge honour, who is modest; Кто скромен, тот u отважен / He who is humble is brave; Kmo скромнее, тот умнее / Those who are more modest are more intelligent; Не хвали себя, а старайся, чтобы другие тебя хвалили / Do not praise yourself, but try to be praised by others; Гордясь славой, не забывай о скромности / Proud of glory, do not forget about modesty; Скромность всякому к лииу / Modesty is becoming to everyone; Скромность - первая заповедь в дружбе / Modesty is the first commandment in friendship).

However, the analysis of the contexts with the lexeme скромность (modesty) shows that modesty in modern Russian society is not always evaluated positively, and numerous contexts that deny its virtue serve as evidence for the transformation of modern values.

(14) Девиз «скромность украшает» сегодня не в моде (Фомин А. Шикарный минимум // За рулем. 2004. 15 марта. НКРЯ). - The motto “modesty adorns" is not in fashion today (Fomin A. Chic Minimum // Za rulyom. 2004. 15 Mar. RNC);

(15) Скромность людей украшает / да / но не сегодня (Беседы с популярными певцами в радиостудии // Из коллекции Ульяновского университета. 2009. НКРЯ). - Modesty adorns people / yes / but not today (Conversations with popular singers in a radio studio // From the Collection of Ulyanovsk University, 2009. RNC).

The revealed modifications of the value component of this communicative concept, due to social changes and globalization conditions, lead to the fact that modesty is not considered an etiquette-moral norm of communication, but is interpreted as an obstacle to career growth and achieving goals:

(16) Каким-то образом он уже начал просекать, что скромность и карьера понятия несовместимые (Рубан Н. Тельняшка для киборга // Боевое искусство планеты. 2003. 18 окт. НКРЯ). - Somehow, he had already begun to catch on that modesty and a career were incompatible (Ruban N. Cyborg Vest // Boevoe iskusstvo planety. 2003. 18 Oct. RNC);

(17) Скромность-это значит не высовываться, не думать о лучшем, не заботиться о своей карьере (Шахиджанян В. 1001 вопрос про ЭТО. № 5011001. 1999. НКРЯ). - To be modest means not to show yourself, not to dream about better life, not to care about your career (Shahidzhanyan V. 1001 Questions About IT. № 501-1001. 1999. RNC).

In fact, a re-thinking of modesty is taking place now. Consequently, it determines the attitude of the society towards a modest person as 
secretive, hiding his shortcomings under the guise of modesty:

(18) - Вы думаете, что скромность действительно украшает? Это придумали бездарные люди, чтобы им не мешали способные и добросовестные. Скромность - оправдание для трусливых (Гранин Д. Нина // Дружба народов. 1999. 15 мая. НКРЯ). - Do you believe modesty really adorns? This was invented by mediocre people, so that they would not be disturbed by the capable and conscientious. Modesty is an excuse for the cowardly (Granin D. Nina // Druzhba narodov. 1999. 15 May. RNC);

(19) Скромность - украшение слабых (Алексиевич С. Время second-hand // Дружба народов. 2013. НКРЯ). - Modesty is the decoration for the weak (Aleksievich S. Second-hand time// Druzhba narodov. 2013. RNC).

The negative attitude of modern Russian speakers is most explicitly revealed through the examples that are aphoristic in form and carnival in essence:

(20) Скромность, слишком бьющая в глаза, это вогнутая наглость (Искандер Ф. Сандро из Чегема. Кн. 3. 1989. НКРЯ). - Modesty which is too eyecatching is a concave impudence (Iskander F. Sandro from Chegem. Book 3. 1989. RNC);

(21) Лучшее украшение девушки - скромность и прозрачное платьице (Шварц Е. Дракон. 1943. НКРЯ). - The best decoration for the girl is modesty and a transparent dress (Schwartz E. The Dragon. 1943. RNC).

A content analysis of the remarks and comments made about modesty on various Internet forums also tends to confirm the conclusion that in modern linguistic consciousness, modesty is evaluated predominantly as a negative quality that interferes with the achievement of goals and is harmful to its holder: The modest ones do not achieve more. They want less (http:/ /www.woman.ru/psycho/personality/thread/ 4391067/); Modesty prevents a person from achieving what he needs, as well as setting goals correctly (http://www.bolshoyvopros.ru/ questions/951448-skromnyj-chelovek-eto-plohoili-horosho.html); The modest are all full of complexes and seldom achieve anything (http:/ /www.woman.ru/psycho/personality/thread/ 4391067/), etc.

The content analysis also shows that in modern Russian society, modesty is perceived as weakness and an invitation to "get a free ride": I know a lot of people who have achieved it they are not modest at all, but arrogant, sometimes vile (all feathering their own nests at the expense of their loved ones), walking over their heads, but achieving. And they do achieve at the expense of the modest ones (http://www.woman.ru/psycho/personality/thread/ 4391067/).

According to our findings, many people, remembering the positive attitude to modesty, acquired in childhood, evaluate this quality ambivalently:

Modesty adorns a person, but makes him poor!

...modesty is both decoration and at the same time ugliness, depending on what to stick on.

...modesty is not the quality that people VALUE, but the one that they USE for their own purposes...

Modesty is gold, but impudence WINS! (http://www.hip-hop.ru/forum/skromnost-horoshoeto-ili-ploho-47612/).

Thus, the conducted content analysis allows us to trace a shift in the value component of the concept 'скромность' ('modesty') in the modern Russian language consciousness towards negative assessment.

'Гнев' ('anger'): A Study into the Inversion of the Linguocultural Value of Emotions. It is well known that the objective phenomena are subject to two types of assessment - emotional and rational. Verbal assessment on the "good - bad" scale is a rational type of measuring the value of objects, events, and actions. Human emotional experiences not only evaluate certain objective phenomena, but are values themselves. Some authors underlines that the value of emotions can be both a moral value mediated by a person's beliefs and an immediate value, rooted in the body's natural need for emotional saturation [Dodonov, 1987]. Thus, we can say that emotions are not only a biological need, but also the greatest universal human value. The linguocultural value of emotions is mediated by the moral values of society, as well as by the attitude to emotions, which is expressed in the rules for the manifestation of specific emotions recognized by society. The linguocultural value of emotions is closely related to religious beliefs, 
norms of behaviour and cultural traditions of society and is an interesting object to study in the framework of axiological linguistics. However, like other values, the value of emotions is also subject to inversion.

We will consider the emotion of anger as an example of the inversion of the linguocultural value of emotions. Anger is one of universal human emotions, the number of which varies, according to research, between five and ten [Ekman, 1984; Izard, 1979]. Anger is included as a basic emotional component - the primary affect - in the structure of such "hot" emotional complexes as hatred, envy, jealousy; its conceptualization is well studied on the basis of various languages and cultures [Kövecses, 1990; 2005; Stefanskiy, 2008; Troneva, 2009; et al.], including our previous research [Pokrovskaya, 1998]. In explanatory dictionaries, anger is defined through the concepts of strong indignation and resentment:

Гнев - 1. Anger is a feeling of strong indignation, resentment (Ozhegov); Гнев 1. Anger is a feeling of intense indignation, a state of extreme irritation or displeasure with smb., smth. (usually intensely manifested) (Slovar sovremennogo russkogo literaturnogo yazyka, vol. 13, col. 170).

Modern scholars agree on the important positive role of anger for human evolution and survival: the main function of anger is active selfdefense (see C. Isard, K. Lorenz, B.I. Dodonov). Currently, the need for this function has almost disappeared, with the exception of cases of selfdefense or protection of the nearest and dearest. In Russian Orthodox culture, the attitude towards anger is extremely negative, except when a pious person is angry against sin. It is interesting that Orthodoxy also recognizes the initially positive role of anger in human development: anger was originally given to man by God to resist evil, to confront vices. But as a result of the fall from grace, anger in people has turned from good power into a sinful passion that "does not produce the righteousness that God desires" (James 1:20).

Archimandrite Raphael (Karelin) writes about two types of anger: natural and sinful, "Natural anger is a necessary property of the human soul, protecting it from the invasion of invisible spiritual snakes - like the immune system protects the human body from agents of disease. This is anger directed against the demon and sin.
It is the guardian of the soul; without it, purity of heart, acquisition of grace, and love for God are impossible. The Bible says of such anger, "Be angry, and do not sin" [Arch. Rafael (Karelin)]. However, the modern perception of anger is associated primarily with the negative bias. Orthodoxy clearly indicates their negative attitude to this emotion: "Anger is a mask of madness, dance of demons, voluntary obsession, brutal relationship between people, a fight of savages. An angry person looks like a wolf that has sunk his teeth into his prey and does not let it go, or like an epileptic who has fallen to the ground and is writhing in agony. When an angry man cannot take his anger out on others, he rushes about in his room like a caged beast, breaks furniture, as if things have done him wrong, punches himself on the head and bites his hands to blood. In this state, a person is sure that he is right about everything and is fighting to establish justice" [Arch. Rafael (Karelin)]. Numerous Russian proverbs and sayings also reflect traditionally negative assessment of an evil and aggressive person. Here are a few examples of a wicked person behaviour: живьем готов съесть (eat alive); съесть с потрохами (chew smb up); стереть с лииа земли (make mincemeat out of smb); в гроб загонит (drive to the grave); свести в могилу (bring smb to his grave); сжить со света (be the death), etc. The value of a bad person (including a wicked, aggressive one) in society is also evaluated negatively; proverbs advise: Бешеному псу уступи дороzy (Give way to the mad dog); Кто с ним свяжется, тот не рад будет (Who will contact him will not be happy); Не дразни собаку она и не укусит (Do not tease the dog - it won't bite); Осиный рой лучше не тревожь (Don't disturb a wasp swarm), etc. The following sayings, for example, remind us that a wicked person is of negative value to society: $3 а$ его гробом и бездомная собака не пойдет (Even a stray dog will not run near his coffin); Собаке собачья смерть (A dog's death for a dog); Пусть ему икается на том свете! (May him hiccup on the other side!); Осиновый кол ему в могилу! (A wooden stake into his grave!).

Our studies into the conceptual representation of anger in Russian linguistic culture have shown that the figurative component of the concept 'гнев' ('anger') is represented by the 
following major conceptual metaphors ANGER IS FIRE, ANGER IS INSANITY, ANGER IS A DANGEROUS ANIMAL, ANGER IS AN ENEMY [Pokrovskaya, 1998, p. 121-139]. It might seem interesting that extensive research into the conceptualization of anger in various unrelated languages (English, Hungarian, Japanese, Zulu, Polish, Chinese, Wolof) have shown that the container metaphor is present in each of them [Kövecses, 2005, p. 197-209]. This allowed Z. Kövecses to conclude that this conceptual metaphor is not only universal, but can be considered an intrinsic property of the human being as a biological species [Kövecses, 2005, p. 209]. The conceptual metaphor ANGER IS INSANITY reflects two basic perceptions of the effect of anger - a person in a state of intense anger cannot function normally like a crazy person: обезуметь, белены объесться (be wild / frantic / crazy), he behaves like a crazy person: взбеситься, рвать и метать, бесноваться (get mad, rave and storm, rampage), which poses a danger to other people. The conceptual metaphor ANGER IS A DANGEROUS ANIMAL demonstrates that animals and aggressive behavior of animals represent a very rich source domain for understanding human aggressive behavior. Not only does this metaphor reflect the ideas about the "animal" part of human nature: озвереть (become like an animal), будить в ком-то зверя (awaken the beast in smb), but it also demonstrates the correlation between the aggressive behavior of a dangerous animal with the behavior of a person in anger: взъерошиться (bristle), показать зубы / когти (show teeth / claws), ощетиниться (raise one's hackles), оскалиться (bare teeth), рычать (snarl), шиnemb (hiss), etc. The perception of anger as a negative emotion leading to undesirable physiological and behavioral reactions, which, in turn, interfere with the normal functioning of the body, provides the basis for a conceptual metaphor ANGER IS AN ENEMY, represented in Russian by expressions: гнев / бешенство душил(о) / овладел(о) / охватил(о) (anger / rage choked / possessed / gripped), подавлять / сдерживать гнев / ярость / бешенство (suppress / keep down anger / rage / fury).

Thus, in Russian linguistic culture, anger and the emotions derived from it (rage, fury, malice, etc.) are considered, first of all, as anti-value; the open expression of anger and other destructive emotions is condemned, as well as aggressive communicative behaviour.

However, recently a sphere of communication, in which the expression of aggressive and destructive emotions predominates, has been demonstrating significat expansion. This is confirmed by a large-scale study aimed at evaluating the changes in the typical psychological image of our fellow citizens between 1981 and 2011. Its findings point to the fact that the Russians have become more conflicted, angrier, more arrogant and in many ways have lost the ability to self-control [Vladykina]. The growing aggressiveness of society is terrible in itself, but the inversion of values, including emotional values, is raising even more fears. As noted above, an extremely important positive role of anger and aggression as a complex bio-socio-psychic phenomenon in phylo- and ontogenesis is beyond doubt. Still we are talking about an emerging shift in the attitude of society towards the communicative manifestations of anger and aggression. Fiction, feature films play a crucial role in the latent acquisition of aggressive behaviour. If a hero of a book or film can or is allowed, in one way or another, to act out his aggressive emotions and these actions are approved (the character is positive, fights evil, saves the world, etc.), then such actions are evaluated positively and the reader (viewer) considers that it is appropriate to behave in a similar way in real life situations. Moreover, human actions and the subsequent (self-) justification of certain aggressive actions are also largely based on a positive evaluation of an aggressive behaviour model. A good example could be H. Kuttner's novel "Fury", in which the protagonist's anger, rage and hatred are presented as a constructive force that changes the world for the better. L. Neykurs' conclusion, based on her survey of respondents, also testifies to lowering of the perception threshold for anger and aggression, it is stated that more than $60 \%$ of people assess angry and threatening intonations as neutral, and this indicates a deep change in our psyche: aggression in the minds of many has become the norm [Neykurs].

\section{Conclusion}

Summing up, we would like to emphasize that changes in the moral values of society 
naturally entail the inversion of communicative and emotional values in Russian linguistic culture.

Truth and modesty as personal features and characteristics of communicative behavior in Russian linguistic culture have traditionally been evaluated positively, and the emotion of anger is negatively marked, which is reflected in the explanatory dictionaries and the paremic fund. Nevertheless, in the modern Russian language consciousness, we have noticed a shift in the value content of the concepts 'правда' ('truth') and 'скромность' ('modesty') towards negative evaluation, while 'гнев' ('anger') reveals positive evaluation, which is reflected in the contexts. Thus, we can state that there is an undergoing process of inversion of linguocultural values.

However, the study poses a number of further questions. In particular, to what extent does the concept 'скромность' ('modesty') interfere with the concepts 'застенчивость' ('shyness') and 'замкнутость' ('moroseness') in the minds of native speakers and how does this affect the shift in the value characteristics of the concept in question? What other initially destructive emotions undergo value transformations? These and many other issues require further study.

\section{REFERENCES}

Archimandrite Rafael (Karelin). O strasti gneva [About Passion of Anger]. URL: http://www. pravoslavie.ru/smi/37600.htm (accessed 15 April 2018).

Bibi S.A., Motet T.P., 2007. Kommunikatsiya i tsennosti [Communication and Values]. Vestnik RUDN [RUDN Journal], no.1, pp. 11-32.

Chesnokov I.I., 2009. Mest kak emotsionalnyy povedencheskiy kontsept (opyt kognitivnokommunikativnogo opisaniya v kontekste russkoy lingvokultury): avtoref. dis. ... d-ra filol. nauk [Revenge as an Emotional Behavioral Concept (Experience of a CognitiveCommunicative Description in the Context of Russian Linguoculture). Dr. philol. sci. abs. diss.]. Volgograd. $44 \mathrm{p}$.

Dementyev V.V., 2010. Teoriya rechevykh zhanrov [The Theory of Speech Genres]. Moscow, Znak Publ. $600 \mathrm{p}$.

Dodonov B.I., 1987. V mire emotsiy [In the World of Emotions]. Kiev, Politizdat. $52 \mathrm{p}$.

Ekman P., 1984. Expression and the Nature of Emotion. Scherer K., Ekman P., eds. Approaches to Emotion. New York, pp. 319-340.
Izard C., 1979. Facial Expression, Emotion, and Motivation. Nonverbal Behavior: Applications and Cultural Implications. New York, Academia Press, pp. 31-49.

Komarov A.S., 2013. Obshchechelovecheskie tsennosti: opyt apologii [Universal Values: Apology Experience]. Perspektivy nauki $i$ obrazovaniya [Perspectives of Science and Education], no. 4, pp. 21-29.

Kövecses Z., 1990. Emotion Concepts. New York, Springer-Verlag. $230 \mathrm{p}$.

Kövecses Z., 2005. Metaphor in Culture: Universality and Variation. Cambridge, Cambridge University Press. $314 \mathrm{p}$.

Leech G.N., 1983. Principles of Pragmatics. London, Longman. $257 \mathrm{p}$.

Neykurs L. Gniloe slovo ubivaet ne khuzhe raka [Rotten Word Kills No Worse Than Cancer]. URL: http://neikurs.com/stati/gniloe-slovoubivaet-ne-huzhe-raka (accessed 20 October 2018).

Pokrovskaya (Volkova) Ya.A., 1998. Otrazhenie v yazyke agressivnykh sostoyaniy cheloveka (na materiale anglo- $i$ russkoyazychnykh khudozhestvennykh tekstov): dis. ... kand. filol. nauk [The Language Reflection of the Aggressive States of a Person (Based on English and Russian Artistic Texts). Cand. philol. sci. diss.]. Volgograd. 188 p.

Prosvirnina I.S., Shao Zh., 2013. Kontsept «skromnost» $v$ russkikh i kitayskikh paremiyakh [The Concept of "Modesty" in Russian and Chinese Proverbs]. Philology and culture, no. 4 (34), pp. 97-104.

Stefanskiy E.E., 2008. Emotsionalnye kontsepty kak fragment mifologicheskoy i sovremennoy yazykovykh kartin mira (na materiale kontseptov, oboznachayushchikh negativnye emotsii $v$ russkoy, polskoy i cheshskoy lingvokulturakh) [Emotional Concepts as a Fragment of Mythological and Modern Language Worldview (Based on Concepts that Denote Negative Emotions in Russian, Polish and Czech Linguistic Cultures]. Samara, Samarskaya gumanitarnaya akademiya. 316 p.

Troneva E.V., 2009. Evfemisticheskaya leksikalizatsiya kontsepta «gnev» v angliyskoy lingvokulture [Euphemistic Lexicalization of the Concept "Anger" in English Linguoculture]. Yazyk. Soznanie. Kommunikatsiya [Language. Consciousness. Communication]. Moscow, Maks Press Publ., iss. 39. pp. 50-56.

Tsennosti $i$ kommunikatsiya $v$ sovremennom obshchestve, 2012 [Values and Communication in Modern Society]. Saint Petersburg, Izd-vo Politekhnicheskogo universiteta. $227 \mathrm{p}$. 
Vladykina T. Seychas vzorvus! [I'll Blow Up Now!]. Rossiyskaya gazeta, 2013, December 23. URL: http://www.rg.ru/2013/12/10/portret.html (accessed 19 May 2018).

Wierzbicka A., 2002. Russian Cultural Scripts: The Theory of Cultural Scripts and Its Applications. Ethos, vol. 30, no. 4, pp. 401-432.

Yakovleva E.A., 1998. Eticheskie kontsepty «pravda, istina» $\mathrm{i}$ «lozh, obman» v makrotekste zhivoy rechi [Ethical Concepts "Truth" and "Lie, Deception" in the Macrotext of Live Speech]. Kulturnye $i$ dukhovnye traditsii russkikh Bashkortostana: istoriya i sovremennost [Cultural and Moral Traditions of Russians in Bashkortostan: History and Modernity]. Ufa, Bashkirskiy gosudarstvennyy universitet, vol. 2, pp. 134-137.

\section{SOUCERS AND DICTIONARIES}

Slovar sovremennogo russkogo literaturnogo yazyka [Dictionary of Modern Russian Literary Language]. Vol. 3. Moscow, Leningrad, Nauka Publ., 1954. 1340 cols.; Vol. 13. Moscow, Leningrad, Nauka Publ., 1962. 1516 cols.
Efremova T.F., ed. Novyy slovar russkogo yazyka. Tolkovo-slovoobrazovatelnyy. V 2 t. T. 1 [The New Explanatory Word-Formative Dictionary of the Russian Language. In 2 Vols. Vol. 1]. Moscow, Drofa Publ., Russkiy yazyk Publ., 2000. 1209 p.

Fasmer M. Etimologicheskiy slovar russkogo yazyka. V 4 t. T. 3 [Etymological Dictionary of the Russian Language. In 4 Vols. Vol. 3]. Saint Petersburg, Terra-Azbuka Publ., 1996. 832 p.

Ozhegov S.I. Slovar russkogo yazyka [Dictionary of the Russian Language]. Moscow, Russkiy yazyk Publ., 1987. 750 p.

Natsionalnyy korpus russkogo yazyka [Russian National Corpus]. URL: http://www.ruscorpora. $\mathrm{ru} / \mathrm{new} /$.

Shanskiy N.M., Bobrova T.A. Shkolnyy etimologicheskiy slovar russkogo yazyka [School Etymological Dictionary of the Russian Language]. URL: http:/www.slovorod.ru/etymshansky/shan-s.htm\#sk (accessed 15 October 2018).

Ushakov D.N., ed. Tolkovyy slovar russkogo yazyka [Explanatory Dictionary of the Russian Language]. URL: http://ushakovdictionary.ru/ (accessed 11 October 2018).

\section{Information About the Authors}

Yana A. Volkova, Doctor of Sciences (Philology), Professor, Department of Foreign Languages in Theory and Practice, Peoples' Friendship University of Russia, Miklukho-Maklaya St., 7, 117198 Moscow, Russia, yana.a.volkova@gmail.com,https://orcid.org/0000-0003-1456-5881

Nadezhda N. Panchenko, Doctor of Sciences (Philology), Professor, Head of the Department of Linguistics, Volgograd State Social-Pedagogical University, Prosp. Lenina, 27, 400066 Volgograd, Russia, panchnn@yandex.ru, https://orcid.org/0000-0003-4498-5262

\section{Информация об авторах}

Яна Александровна Волкова, доктор филологических наук, профессор кафедры теории и практики иностранных языков, Российский университет дружбы народов, ул. Миклухо-Маклая, 7 117198 г. Москва, Россия, уana.a.volkova@gmail.com, https://orcid.org/0000-0003-1456-5881

Надежда Николаевна Панченко, доктор филологических наук, профессор, заведующая кафедрой языкознания, Волгоградский государственный социально-педагогический университет, просп. Ленина, 27, 400066 г. Волгоград, Россия, panchnn@yandex.ru, https://orcid.org/0000-0003-4498-5262 